\title{
MINIMAL RESIDUAL DISEASE, ITS DETECTION AND SIGNIFICANCE IN HAIRY-CELL LEUKEMIA
}

\author{
Pavel Žák ${ }^{1}$, Ladislav Chrobák ${ }^{1}$, Karel Dédič ${ }^{2}$ \\ University Teaching Hospital in Hradec Králové: Department of Clinical Haematology ${ }^{1}$; Charles University in Prague, \\ Faculty of Medicine in Hradec Králové: The Fingerland Department of Pathology ${ }^{2}$
}

Summary: As minimal residual disease (MRD) is considered the detection of hairy cells (HCs) in a patient with hairy cell leukemia (HCL) in complete remission with the absence of detectable HCs by routine morphology of peripheral blood, aspirates and bone marrow core sections, using more sensitive methods of identification as immunohistological staining or polymerase chain reaction (PCR) to detect immunoglobulin heavy chain genes rearrangement. Various monoclonal antibodies (MoAbs) as CD20, DBA.44, B ly-7, HC2, CD25 and CD11c have been applied using immunological staining. There is no standardized technique for identification of MRD . According to the technique used the MRD has been detected in $13 \%$ to $100 \%$ of patients in complete remission (CR). It may be concluded that many patients, if not all, in stable CR may have residual HCs. Whether MRD will have impact on early relapse or on long term outcome, or whether patients in CR with persistant MRD will remain so, is a matter of a longer follow-up.

Key words: Hairy cell leukemia; Minimal residual disease; Detection; Significance

Supported by Grant IGA No. 4101-3 from the Ministry of Health of the Czech Republic.

\section{Introduction}

Hairy cell leukemia (HCL) is a clonal chronic lymphoproliferative disorder characterized by pancytopenia, splenomegaly without significant lymphadenopathy, and by abnormal mononuclear cells of B cell origin infiltrating bone marrow and spleen (15). It is a distinct clinical and pathological entity (5). Although the disease is relatively indolent, the majority of patients require treatment for lifetreatening pancytopenia or symptomatic splenomegaly. Splenectomy has been used for over three decades as the initial treatment option $(10,11,15,16)$. Splenectomy has been certainly beneficial for some patients resulting in a significant improvement of their pancytopenia. On the other hand splenectomy had no effect on bone marrow infiltration of HCs. As a result, approximately $50 \%$ of splenectomized patients had recurrent cytopenias that required systemic therapy. The introduction of interferon - alfa (IFN) in 1984 (22) and two new purine analogues, 2-deoxycoformycin (DCF) in 1984 (23) and 2-chlorodeoxyadenosine (2-CdA) in 1990 (24) in therapy of HCL dramatically improved treatment option of $\mathrm{HCL}$ in the last years.

IFN has been shown to induce complete remission in $11 \%$ of patients (range $0 \%$ to $30 \%$ ), DCF in $68.5 \%$ of patients (range $42 \%$ to $93 \%$ ) and 2-CdA in $85 \%$ of patients (range $75 \%$ to $91 \%$ ) (14). IFN - alfa was the first drug in which the possibility to cure HCL was originally considered. The expectance was not fulfilled. IFN - alpha was highly effective in the management of HCL but did not eradicate and cure the disease. Relapses were observed after withdrawal of the therapy in all patients. DCF and 2-CdA were able to induce complete remission in the majority of the patients. The complete remission has been defined according to the criteria decleared on the Third International Workshop on Hairy Cell Leukemia in 1990 (4) as complete absence of morphological evident HCs in the peripheral blood and bone marrow using routine light microscopy, normalization of peripheral blood cell counts and absence of palpable adenopathy and hepatosplenomegaly.

Nevertheless CR is often associated with finding of residual leukemic population (MRD) in the bone marrow if more sensitive immunohistochemical methods or PCR technique to detect immunoglobulin heavy chain genes rearrangement are applied. The definition of MRD is difficult, because standardized criteria of MRD identification are lacking.

MRD has been observed in patients treated with IFN alpha (8), DCF $(19,24)$ and 2-CdA $(1,2,7,9,12,18,26$, 27) (tab.1). MRD was found in $13 \%$ (26) to $100 \%(2,9,13$, $18,24)$ of patients depending on the method used. Southern blot analysis (6) has been found not to be sensitive for detection of MRD.

The significance of MRD for early relapse and survival rate has to be established. 
Tab. 1: Minimal residual disease.

\begin{tabular}{|c|c|c|c|c|c|c|c|c|c|}
\hline \multirow[t]{2}{*}{ No } & \multirow[t]{2}{*}{ Author } & \multirow[t]{2}{*}{$\begin{array}{l}\text { References } \\
\text { (No) }\end{array}$} & \multicolumn{2}{|c|}{$\begin{array}{c}\text { Number } \\
\text { of investigations }\end{array}$} & \multirow[t]{2}{*}{$\%$} & \multicolumn{3}{|c|}{$\begin{array}{c}\text { Method } \\
\text { (Type of Monoclonal Antibody }\end{array}$} & \multirow[t]{2}{*}{ Therapy } \\
\hline & & & $\begin{array}{l}\text { MRD+ } \\
\text { positive }\end{array}$ & Total & & Anti-B cells & Anti-T cells & other & \\
\hline 1. & Hakimian et al. & 12 & 5 & 24 & 21 & $\begin{array}{c}\mathrm{L} 26(\mathrm{CD} 20) \\
\mathrm{MB} 2(\mathrm{CD} 45 \mathrm{RO})\end{array}$ & UCHL-1 & & 2-CdA \\
\hline 2. & Wheaton et al. & 26 & 5 & 39 & 13 & $\begin{array}{c}\text { CD20 } \\
\text { DBA.44 }\end{array}$ & CD45RO & & 2-CdA \\
\hline 3. & Hounieu et al. & 13 & 41 & 41 & 100 & DBA.44 & & & \\
\hline 4. & Žák et al. & 27 & 11 & 12 & 92 & DBA.44 & & & 2-CdA \\
\hline 5. & Bastie et al. & 1 & 8 & 22 & 36 & DBA.44 & & & $\begin{array}{c}2-\mathrm{CdA} \\
(1-2 \text { cycles })\end{array}$ \\
\hline 6. & Falini et al. & 8 & 7 & 9 & 78 & $\begin{array}{l}\text { CD45RA (4KB5) } \\
\text { L26 (CD20) }\end{array}$ & & & IFN-alpha2 \\
\hline 7. & Ellison et al. & 7 & 79 & 158 & 50 & $\begin{array}{l}\text { L26 (CD20) } \\
\text { DBA. } 44\end{array}$ & & & 2-CdA \\
\hline 8. & Matutes et al. & 19 & 10 & 23 & 43 & $\begin{array}{l}\text { CD25, CD11c } \\
\text { B-ly7,HC2 }\end{array}$ & & & DCF \\
\hline 9. & Thaler et al. & 24 & 4 & 4 & 100 & B-1y7 & & & $\mathrm{DCF}$ \\
\hline 10. & Konwalinka et al. & 18 & 11 & 11 & 100 & B-ly7 & & & 2-CdA \\
\hline 11. & Filleul et al. & 9 & 10 & 10 & 100 & & & PCR & 2-CdA \\
\hline 12. & Carbone et al. & 2 & 4 & 4 & 100 & & & PCR & 2-CdA \\
\hline 13. & Di Celle et al. & 6 & 0 & 4 & 0 & & & \begin{tabular}{|c|} 
Southern \\
Blot
\end{tabular} & 2-CdA \\
\hline
\end{tabular}

Detection of MRD:

Hakimian et al. (12) used two B - lineage antibodies, L26 (anti CD20) and MB2 and T lineage antibody UCHL1 (CD45RO) to evaluate core biopsies from 34 patients before and after treatment with 2-CdA. L26 (anti CD20) is a pan-B-cell antibody that is highly lineage specific. L26 (CD20) typically stains positively in most cases of HCL (13). UCHL-1 does not react with hairy cells. Five of 24 (21\%) patients in CR by routine evaluation had MRD detected by immunostaining. Four of these 5 patients have been reevaluated at 1 year. One patient relapsed by routine evaluation, two remained positive by immunostaining alone, and one patient became negative by immunostaining.

Hakimian et al. stress that immunostaining using the Blineage antibody is contributory to quantifying the extent of disease, particularly when HCs are interstitial and blended with surrounding hematopoietic tissue, when HCs are present among fat cells in hypocellular marrow, when they are spindel-shaped, and when marrows are markedly fibrotic.

The postherapy bone marrow sections were interpreted as positive for residual $\mathrm{HCs}$ if the following two criteria were met:
1. the L26 (CD20) - positive cells had the morphologic appearance of $\mathrm{HCs}$,

2. the cells reacting with L26 (CD20) were more numerous than those reacting with

UCHL-1 (CD45RO). Normally the T-cell are in bone marrow more numerous.

Wheaton et al (26) used also the combination of two Blineage antibodies anti CD20 and DBA.44 and one T lineage antibody anti CD45RO (UCHL-1). They studied paraffin - embedden bone marrow core biopsies from 39 patients with HCL in CR 3 months after a single cycle of 2$\mathrm{CdA}$ and annualy therafter. MRD was detected in 5 of 39 (13\%) patients. Two of the five patients (40\%) with MRD at 3 months have relapsed, whereas only 2 of 27 (7\%) with no MRD and at least one year of follow-up relapsed.

They used nearly the same criteria as Hakimian at al. (12) defining MRD: The presence of CD20 or DBA.44 (Bcell) - positive cells in equal or greater numbers than CD45RO (T-cell) - positive cells and the presence of greater than $50 \%$ of the CD20 or DBA.44 positive cells exhibiting morphologic features consistent with HCs.

As HCs were identified CD20- or DBA.44 - positive cells with moderate to abundant cytoplasm and distinct cy- 
toplasmic projections. CD20 demonstrated strong surface membrane positivity, whereas DBA.44 exhibited both cytoplasmic and surface membrane positivity. DBA. 44 also outlines the cytoplasmic projections of hairy cells, however it tended to obscure the nuclear detail due to the intense cytoplasmic positivity.

Wheaton et al (26) admit that the used criteria may underestimate the true incidence of MRD, but they consider that they may detect a treshold of MRD that has clinical importance.

Ellison et al. (7) used as well the combination of L26 (CD20) and DBA.44 antibodies. Out of 154 bone marrow biopsies 50\% exhibited staining with L26 and/or DBA.44 in five or more cells with morphologic features of hairy cells. HCs represented usually less than $1 \%$ of the total cellular population. In control bone marrow specimens DBA.44 stained only rare cells, fewer than one per highpowered field and usually only a few (less than 10) cells in entire biopsy. Because of the difficulties in identifying some L26 - / DBA.44 - positive lymphocytes as either hairy cells or reactive lymfocytes, a bone marrow was considered positive for residual hairy cells when five or more cells with both nuclear and cytoplasmic morphology features of hairy cells and with a characteristic pattern of staining with L26 and/or DBA.44 were positive. Ellison et al considered that some of the cases that had one to four HCs by immunomorphologic analysis were true positive. They observed HCL patients after 2-CdA therapy for up to 25 months after therapy. The amount of residual disease seemed to remain stable over a prolonged period of time in majority of patients.

Only DBA.44 antibody has been used by Hounieu et al. (13), Bastie et al. (1) and Žák et al. (27).

Bastie et al. (1) defined MRD as $1 \%$ to $5 \%$ DBA. 44 positive cells in bone marrow biopsies with no evidence of HCs by routine morphologic examination. At 6 months 8 of 22 (36\%) patients in CR had residual disease by immunohistologic staining.

Hounieu et al. (13) evaluated bone marrow biopsy specimens from 166 patients with HCL and in 75 patients after therapy with IFN-alpha. In 41 patients the bone marrow infiltrates assessed by standard microscopy as doubtful or none were found positive after DBA.44 staining.

Some observation not directly associated with the detection of MRD are noteworthy. First immunostaining with DBA.44 disclosed topografic variations in HCL infiltrates in bone marrow some areas were massively involved, whereas other areas showed minimal to moderate involvement. Second, in two cases with an intense fibroblastic reactions of the marrow, HCs were clearly detected among fibroblasts. Third, in two other cases, non-neoplastic nodular lymphocytic infiltrates remained unstained by DBA.44.(13)

Žák et al. (27) used for detection of HCs and MRD bone core biopsies immunostained with DBA.44. To quantify and compare the positive findings the morphometric quantitative computer study of trephine bone marrow biop- sy was performed on three high power fields $\left(65265 \mu \mathrm{m}^{2}\right)$. MRD was found in 11 of 12 patients (92\%) with $1 \%$ to $18 \%$ DBA.44 positive cells (median 4\%). The CR duration was 16 to 43 months (median 30 months). The low infiltration of HCs in their study was reflected by very low levels of sIL$2 \mathrm{R}$ which is considered as noninvasive marker of tumor mass.

Fallini et al. (8) used a panel of monoclonal antibodies directed against B-cell and hairy cell leukemia - associated antigens to identify residual HCs in bone marrow samples from 20 patients with HCL. They concluded that the best markers for identifying residual HCs in routine bone marrow biopsies were CD45RA (MAb 4KBS) and CD20 (MAb L26).

Matutes et al. (19) investigated the clinical significance and long-term follow-up of detecting MRD in HCL after treatment with DCF. MRD was asessed in 23 patients by immunophenotyping using a panel of antibodies : CD11c, CD25, CD103 and HC2 which detect HCs. MRD had 10 of 23 (43\%) patients. At a median follow-up of 72 months (range 15-108), 5 of 23 (22\%) patients have relapsed with a median time of 59 months (range 15-105). MRD was detected in three of five patients who relapsed. MRD was documented in 7 of 18 who continued in clinical CR for a median of 80 months (range 63-98). There were no statistical differences in disease free survival between MRD+ and MRD- patients. These findings indicate that relapse after long-term remission achieved with DCF cannot be predicted when MRD is detected by sensitive methods. On the other hand, although differences for a risk of relapse between patients with MRD+ or MRD- lack statistical significance, there was a slight trend for a higher probability of relapse in patients with MRD+.

Excellent experiencies with monoclonal antibody B-ly7 (anti CD103) in HCL reported Thaler et al.(24). They investigated cryostat sections of bone marrow biopsies by an indirect immunoperoxidase technique. The strong reactivity of HCs with this marker was not altered after therapy with IFN-alpha2 or DCF six to sixty four weeks after start of treatment. Moderate to strong membrane staining of HCs by the MoAb B-ly7 facilitates morphological identification of these cells. The typical cytoplasmic projections are clearly visible on the B-ly7 stained cryostat sections. Normal bone marrow contains only a small number of Bly7 positive cells ranging from 0.0 to $1.0 \%$ (mean $0.3 \%$ ), whereas the percentage of cells recognized by pan-B cell markers in normal marrow is considerably higher. CD22 stains $0.7-3.0 \%$ (mean $1.7 \%$ of bone marrow cells). (24)

Residual HCs were detectable immunohistologically with the MoAb B-ly7 in all of the four patients in CR according to the morphological bone marrow examination and generally accepted criteria (4).

The high sensitivity of MoAb B-ly7 has been confermed by Konwalinka et al. (18). They detected MRD in 11 patients with CR of HCL after 2-CdA therapy. At a follow-up period of 7-29 months (median 19.3 months) 9 of these pa- 
tients remained in CR, whereas 2 patients relapsed 22 and 27 months after 2-CdA therapy.

To determine whether flow-cytometric assay of bone marrow aspirates and peripheral blood cells is comparable with results obtained by immunostaining with B-ly7 in bone marrow biopsies, flow cytometric data were analysed obtained from patients 91 to 1,046 days (median 345 days) after 2CdA treatment. In 5 of 10 cases no HCs could be detected in bone marrow aspirates by using two-colour flow cytometry with CD19/CD11c. However, immunostaining using B-ly7 still revealed HCs (ranging from 0.1 to $7.5 \%$ ) in these cases.

The presence of MRD after one course of 2-CdA was investigated by Filleul et al. (9) in 10 patients in CR using the polymerase chain reaction (PCR), and heavy chain immunoglobulin genes or TCR- $\delta$ derived clonospecific probes. Using PCR 7 evaluable patients remaining in CR at six months showed persistent evidence of detectable MRD with no sign of decrease over the observation period, in four patients for more than 12 months. Carbone et al. (2) got a positive PCR in all four patients in CR after a single 1-week course of continous intravenous infusion of $0.1 \mathrm{mg} / \mathrm{kg} /$ day of $2-\mathrm{CdA}$. Di Celle applied in these four patients Southern blot analysis of the IgH chain gene configuration and got germline configuration of IgH chain genes in all four patients suggesting CR without of MRD. Filleul et al. (9) got using Southern blot germline configuration in all 8 patients with CR and stress that Southern blot techniques can detect at best $5 \%$ of leukemic cells, and the detection is even more difficult in HCL, because aspirates are frequently unsuccessful or may underestimate residual disease due to its focal nature.

We can conclude that methods sensitive for detecting MRD include immunostaining and Ig genes rearrangement studies using PCR. Immunohistologic studies are more sensitive for detecting residual hairy cells than morphology alone. Despite limited experience, the PCR rearrangement analysis of immunoglobuline genes seems to be the most sensitive. The results indicate that the amount of residual HCs seems to remain stable over a prolonged period of time in the majority of patients.

\section{Conclusion}

The true significance of MRD has to be established. A standardized technique for detection of MRD is needed. According to the literature data and our own experience a more prolonged follow-up, possibly using quantitative determinations of MRD on larger series of patients will help us to assess the impact of MRD on the relapse rate and overall survival.

\section{References}

1. Bastie JN, D'Agay MF, Flandrin G et al. Hairy cell leukemia (HCL): phase II prospective study about 28 patients treated with 2-chlorodeoxyadenosin (2CdA). $\mathrm{Br}$ J Haematol 1994:87(suppl 1):209-14.

2. Carbone A, Reato G, Di Celle PF et al.: Disease eradication in hairy cell leukemia patients treated with 2-chlorodeoxyadenosine. Leukemia 1994;8:2019-21.
3. Cartun R, Coles F, Pastuszak W. Utilization of monoclonal antibody L26 in the identification and configuration of B-cell lymphomas. Am J Pathol 1987;129:415-9.

4. Catovsky D, Golde DW, Golomb HM. Meeting report. The third international workshop on hairy cell leukemia. Laguna Niguel, California 19-20 October 1989. Br J Haematol 1990;74:378-9.

5. Catovsky D, Pettit JE, Galton DA et al. Leukemia reticuloendoteliosis („hairy cell leukemia“) a distinct clinico-pathologic entity. Br J Haematol 1974;26:9-27.

6. Di Celle PF, Reato G, Raspadori D, et al.: Molecular evaluation of clonal remission in hairy cell leukemia patients treated with 2-chlorodeoxyadenosine. Leukemia Lymph 1994;14(Suppl 1):139-42.

7. Ellison DJ, Sharpe RW, Robbins BA et al. Immunomorphologic analysis of bone marrow biopsies after treatment with 2-chlorodeoxyadenosin for hairy cell leukemia. Blood 1994;84:4310-15.

8. Falini B, Pileri A, Fleghi L et al. Selection of a panel of monoclonal antibodies for monitoring residual disease in peripheral blood and bone marrow in interferon - treated hairy cell leukemia patients. Br J Haematol 1990;76:460-8.

9. Filleul B, Delannoy A, Ferrant A et al. A single course od 2-chlorodeosyadenosine does not eradicate leukemic cells in hairy cell leukemia patients in complete remission. Leukemia 1994;8:1253-6.

10. Flandrin G, Sigaux F, Castaignes $\mathrm{S}$ et al.: Leucémie à tricholeucocytes: étude de l'évolution de 211 cas. Presse Méd 1984;13:2795-9.

11. Golomb HM, Wardiman JW. Response to splenectomy in 65 patients with hairy cell leukemia: An evaluation of spleen weight and bone marrow involvement. Blood 1993;61:349-52.

12. Hakimian D, Tallman MS, Kiley $\mathrm{C}$ et al. Detection of minimal residual disease by immunostaining of bone marrow biopsies after 2-chlorodeoxyadenosine for hairy cell leukemia. Blood 1993;82:1798-802.

13. Hounieu H, Chita S, Al Saati T et al. Hairy cell leukemia. Diagnosis of bone mar row involvement in paraffin - embedded sections with monoclonal antibody DBA.44. Am J Clin Pathol 1992:98:26-33.

14. Chrobák L. Leukemie s vlasatými buňkami. Galén: Praha, 1999.

15. Chrobák L, Podzimek K, Kerekeš Z et al. Long-term results in hairy cell leukemia treated by splenectomy. Neoplasma 1993;40:133-6.

16. Jansen J, Hermans J, Remme J et al. Hairy cell leukemia. Clinical features and effect of splenectomy. Scand J Haematol 1978;21:60-71.

17. Jansen J, Schutt HRE, van Zwett ThL et al. Hairy cell leukemia. A B-lymphocytic disorder. Br J Haematol 1979;42:321-30.

18. Konwalinka G, Schirmer M, Hilbe W et al. Minimal residual disease in hairy-cell leukemia after treatment with 2- chlorodeoxyadenosine. Blood Cells Mol Dis $1995 ; 21: 142-51$.

19. Matutes E, Meeus D, Mc Lennan K et al. The significance of minimal residual disease in hairy cell leukemia treated with deoxycoformycin: a long term followup study. Br J Haematol 1997;98:375-83.

20. Piro LD, Carrera CJ, Carson DA. Lasting remission in hairy cell leukemia induced by a single infusion of 2-chlorodeoxyadenosine. N Engl J Med 1990;322:1117-21.

21. Pulford KAF, Falini B, Heryet A et al. 4KB5, a new monoclonal anti-B cell antibody for the routine diagnosis of lymphoid tissue biopsies. Leukocyte Typing III, 1998; ed. by Mc Michael A.J. et al.: 828 Oxford University Press.

22. Quesada JR, Manning JT, Hersh EM et al. Alfa interferon for induction of remission in hairy cell leukemia. N Engl J Med 1984;310:15-8.

23. Spiers ASD, Parekh SJ, Bishop MB et al. Hairy-cell leukemia induction of comlete remission with pentostatin (2'deoxykoformicin). J Clin Oncol 1984;2:1336-42.

24. Thaler J, Dietze O, Faber V et al. Immunohistological assessment of bone marrow biopsies from patients with hairy cell leukemia: changes following treatment with alpha2-interferon and deoxykoformycin. Leukemia Res 1989;13:377-82.

25. Visser L, Shaw A, Slupsky J et al. Monoclonal antibodies reactive with hairy cell leukemia. Blood 1989;74:320-25.

26. Wheaton S, Tallman MS, Hakimian D et al. Minimal residual disease may predict bone marrow relapse in patients with hairy cell leukemia treated with 2-chlorodeoxyadenosine. Blood 1996;87:1556-60.

27. Žák P, Dědič K, Chrobák L. The bone marow content of DBA.44 - positive hairy cells in patients with hairy cell leukemia $(\mathrm{HCL})$ in clinical hematological remission. Haematologica 1999;84:24.

Submitted August 1999.

Accepted September 1999. 